University of Nebraska - Lincoln

DigitalCommons@University of Nebraska - Lincoln

USDA Wildlife Services - Staff Publications

U.S. Department of Agriculture: Animal and Plant Health Inspection Service

$5-19-2019$

\title{
The economic impacts of blackbird (Icteridae) damage to sunflower in the USA
}

\author{
Karina Ernst \\ USDA APHIS Wildlife Services, karina.h.ernst@aphis.usda.gov \\ Julie Elser \\ USDA APHIS Wildlife Services
}

George Linz

USDA APHIS Wildlife Services

Hans Kandel

North Dakota State University--Fargo

Jason Holderieath

USDA APHIS Wildlife Services

Follow this and additional works at: https://digitalcommons.unl.edu/icwdm_usdanwrc

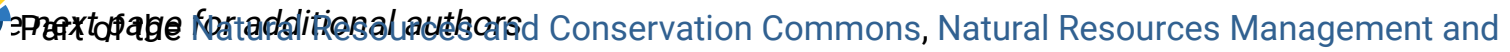
Policy Commons, Other Environmental Sciences Commons, Other Veterinary Medicine Commons, Population Biology Commons, Terrestrial and Aquatic Ecology Commons, Veterinary Infectious Diseases Commons, Veterinary Microbiology and Immunobiology Commons, Veterinary Preventive Medicine, Epidemiology, and Public Health Commons, and the Zoology Commons

Ernst, Karina; Elser, Julie; Linz, George; Kandel, Hans; Holderieath, Jason; DeGroot, Samantha; Shwiff, Steven; and Shwiff, Stephanie, "The economic impacts of blackbird (Icteridae) damage to sunflower in the USA" (2019). USDA Wildlife Services - Staff Publications. 2278.

https://digitalcommons.unl.edu/icwdm_usdanwrc/2278

This Article is brought to you for free and open access by the U.S. Department of Agriculture: Animal and Plant Health Inspection Service at DigitalCommons@University of Nebraska - Lincoln. It has been accepted for inclusion in USDA Wildlife Services - Staff Publications by an authorized administrator of DigitalCommons@University of Nebraska - Lincoln. 


\section{Authors}

Karina Ernst, Julie Elser, George Linz, Hans Kandel, Jason Holderieath, Samantha DeGroot, Steven Shwiff, and Stephanie Shwiff 


\title{
The economic impacts of blackbird (Icteridae) damage to sunflower in the USA
}

\author{
Karina Ernst, ${ }^{a^{*}} \odot$ Julie Elser, ${ }^{a}$ George Linz, ${ }^{b}$ Hans Kandel, ${ }^{\mathrm{c}}$ \\ Jason Holderieath, ${ }^{\mathrm{a}} \odot$ Samantha DeGroot, $^{\mathrm{d}}$ Steven Shwiffe and \\ Stephanie Shwiff ${ }^{a}$
}

\begin{abstract}
BACKGROUND: Blackbird (Icteridae) damage to ripening sunflower (Helianthus annuus L.) has been a persistent economic issue in the USA for the last five decades. To quantify losses, we surveyed blackbird damage from 2001 to 2013 (excluding 2004 ) to physiologically mature sunflower in eight states: North Dakota, South Dakota, Texas, Nebraska, Minnesota, Colorado, Kansas, and Vermont.

RESULTS: We pooled data gathered during the most recent 5 years (2009 to 2013) of the survey and found losses averaged \$US2.5 million and \$US11.3 million for confectionery and oilseed hybrids, respectively. Three states, North Dakota, South Dakota, and Nebraska, had sufficient acreage and bird damage to warrant economic analyses using a regional economic model. The average annual total (direct plus indirect) economic impact of bird damage to sunflower production for North Dakota, South Dakota, and Nebraska was \$US18.7 million, \$US7.3 million, and \$US2.6 million, respectively.

CONCLUSION: This study provides a better understanding of the broader economic implications of bird damage to sunflower by estimating the macroeconomic impacts of lost sunflower production in the region. Additionally, the findings of this study may be used to inform decisions regarding bird management policy by providing policymakers with information to determine the downstream value of bird management and the possible benefits of improved methods that further mitigate losses.

(c) 2019 Society of Chemical Industry
\end{abstract}

Keywords: blackbirds; crop damage; Icteridae; economic impact; prairie pothole region; sunflower

\section{INTRODUCTION}

Sunflower (Helianthus annuus L.) is a globally important oilseed crop, native to North America. It has been cultivated as a commercial crop since the late 1960s. ${ }^{1}$ Sunflower production is concentrated in the North Midwest of the USA, specifically in what is known as the Prairie Pothole region (PPR) in South Dakota and North Dakota. ${ }^{2}$ Though too dry and windy for other crops to survive, the PPR has ideal soils and climate conditions for sunflowers due to their deep root structure. ${ }^{3}$ Sunflower yields in this region surpass $1800 \mathrm{~kg}$ per hectare $\left(\mathrm{kg} \mathrm{ha}^{-1}\right) .^{2}$ In fact, of the 1344700 acres of sunflower harvested in the USA in 2017, 426000 acres were harvested in North Dakota and 594000 acres were harvested in South Dakota, comprising $75 \%$ of US sunflower production. ${ }^{4}$

Today's sunflower crop is almost entirely consumed domestically, and roughly a quarter of all sunflower seed is used in birdseed. $^{3}$ Due to their thin hulls and high oil content sunflower seeds are a premium birdseed ingredient. A 2006 survey showed that consumers spent \$US2.7 billion on commercially prepared birdseed. ${ }^{3}$ Another $10-12 \%$ of commercially produced sunflower seed is sold directly for snacks and baking products, and multiple small confectionary processing plants are located throughout sunflower-producing states to take advantage of local distribution ${ }^{3}$

While the PPR caters to sunflower growth, its potholes also provide refuge for migrating and resident blackbirds (Icteridae). Millions of blackbirds roost in cattail-dominated (Typha spp.) wetlands during fall migration, and large mixed-species flocks form at roosting sites by mid-August. ${ }^{2,5}$ Blackbirds are opportunistic granivores, and flocks of foraging blackbirds can number up to 1000. ${ }^{2}$ As wetlands tend to be near sunflower fields, blackbird damage to sunflower is a major economic problem for growers in the American Midwest, specifically in North Dakota, South Dakota, and Minnesota. ${ }^{6}$ Sunflower producers in North Dakota have cited blackbirds as their number one production problem, and the primary culprits are the red-winged blackbird (Agelaius, phoeniceus L.), the yellow-headed blackbird (Xanthocephalus xanthocephalus B.), and the common grackle (Quiscalus quiscula L.)., 5l, Blackbirds caused about \$US3.6 and \$US6.5 million in sunflower damage in North Dakota in 1979 and 1980, respectively. ${ }^{7}$

\footnotetext{
* Correspondence to: K Ernst, National Wildlife Research Center, USDA APHIS Wildlife Services, 4101 LaPorte Ave, Fort Collins, CO, 80521, USA. E-mail: karina.h.ernst@aphis.usda.gov

a National Wildlife Research Center, USDA APHIS Wildlife Services, 4101 LaPorte Ave, Fort Collins, CO, USA

b National Wildlife Research Center, USDA APHIS Wildlife Services, Biological Sciences, Dept. 2715 North Dakota State University, PO Box 6050, Fargo, North Dakota, USA

c Department of Plant Sciences, 1360 Albrecht Blvd. Loftsgard Hall, North Dakota State University, Fargo, North Dakota, USA

d Veterinary Services, USDA APHIS, CO, USA

e Texas A\&M Commerce, Commerce, Texas, USA
} 
Blackbirds reach their highest densities in the Northern Great Plains at the same time sunflowers near maturity, at the end of the flowering period (anthesis) when the last of the ray petals drop from each flower and achenes (fruit containing the seed) begin to develop. ${ }^{2,5}$ It is at this stage when the sunflower seeds are at their softest and most vulnerable to bird damage. ${ }^{6}$ Cummings et al. ${ }^{6}$ found that blackbirds prefer seeds in soft stages, and that flocks of foraging birds will actually leave more mature fields of sunflower to seek fields with softer achenes. Their study showed that $75 \%$ of total bird damage to sunflower occurs within the first 18 days after anthesis, and continues, decreasing gradually, until harvest in October.

A study performed by Klosterman et al. ${ }^{8}$ examined the damage made to 120 randomly selected corn (Zea mays L.) and sunflower plots in the PPR region of North Dakota over a 2-year period. They found that the average annual damage caused by blackbirds to the selected 27 sunflower fields was 7500 tons. They also estimated that blackbird damage to sunflower in North Dakota averages \$US3.5 million. In a similar study, Peer et al. ${ }^{5}$ used bioenergetic and economic models to estimate the damage made to sunflower by the three most prominent blackbirds: red-winged blackbirds, yellow-headed blackbirds, and the common grackle. They estimated that all three bird populations cause a total of \$US5.4 million in sunflower damage annually.

It can be argued that region-wide estimates of bird damage do not convey the true nature of bird damage because bird damage is unevenly distributed across sunflower producers. ${ }^{1,5}$ Leitch et al. ${ }^{9}$ argue that the severity of bird damage to sunflower fields can vary due to multiple factors. The main factors include the size of the sunflower field, its proximity to a roost wetland, the bird population at the wetland, and how much time birds spend at sunflower fields. Evidence of damage studied by Linz and Homan ${ }^{10}$ supports the finding that sunflower fields planted closer to wetlands usually experience more depredation. They explain that bird damage to sunflower fields planted near cattail-dominated wetlands is considered to be economically unsustainable, often forcing growers to discontinue the incorporation of sunflower into their planting rotations. Leitch et al. ${ }^{9}$ found that fields within $3 \mathrm{~km}$ of roost wetlands experienced losses up to $15 \%$, compared to fields planted $6 \mathrm{~km}$ from wetlands which experienced $8 \%$ losses.

Bird damage to agricultural crops is often perceived to be a problem that primarily impacts producer profits, but the impacts of sunflower depredation extend beyond the producer and the sunflower industry, creating what is known as a "farm to fork" loss in the economy. This term refers to losses that extend to all industries involved from the minute a sunflower is harvested to the point at which it is consumed. For example, intermediate facilities that process sunflower seeds into oil most likely purchase bottles and labels from other linked businesses, generating economic activity in those sectors. In addition, workers are paid to process and package the sunflower oil, which is then transported to stores for purchase, which incorporates transportation, advertising, and retail industries as well. Therefore, as this intermediate facility transforms sunflower seeds into oil, value is added throughout the entire supply chain, ultimately ending up at the retail and household level. Fewer sunflower seeds entering the system means reduced oil production, which in turn results in decreased demand for bottling, labeling, workers, transportation, extending to all linked industries. This impacts the entire region. Regional economic modeling provides a way to calculate the impact to linked industries as a result of diminished sunflower production. In doing so, we can calculate the future impacts that blackbird damage to sunflower crop can have on the region and the value of bird damage management.

This study integrates the damage caused by blackbird populations to sunflower crops in impacted states with the regional economy. Our methodology is in line with work by Hirsch and Leitch $^{11}$, which developed a framework for the estimation of the economic impacts to the state of Montana from three species of invasive knapweed (Centaurea diffusa, C. maculosa, and Acroptilon repens L.), and Shwiff et al. ${ }^{12}$, which examined the regional economic impacts to tourism from cormorant (Phalacrocoracidae B.) predation to a sport fishery. This analysis will elucidate the economic impacts of bird damage to both producers and consumers, and may be useful for policy makers when considering management options and for producers when making implementation decisions.

\section{METHODS}

\subsection{Study area}

For this field study, 721 physiologically mature sunflower fields were randomly sampled (Table 1) from mid-September to early October 2009-2013 in North Dakota, South Dakota, Texas, Nebraska, Minnesota, Colorado, Kansas, and Vermont by 32 to 60 trained teams, including agronomists, entomologists, pathologists, crop consultants, and producers as described in the annual National Sunflower Association Survey. ${ }^{13-17}$ Yield and bird damage was estimated from one production field for every 4047 to 6070 ha of sunflower planted in 951 sunflower fields. ${ }^{18}$ Within a field, two random locations were visited to estimate percent loss due to blackbird depredation. One estimate was taken no less than $25 \mathrm{~m}$ from the edge of the field and the other no less than $100 \mathrm{~m}$ from the edge of the field.

As described by Kandel and Linz ${ }^{18}$, head diameter was measured for five consecutive heads in the row using five wedges, one from each head. The wedges were cut out of the head and seeds were hand shelled to determine average seed size by comparing the seed with a chart. ${ }^{19}$ To determine seed fill and percent filled seed, 100 seeds were evaluated. The center of the head without seeds was measured and subtracted from the production estimate. Loss due to bird damage was estimated based on sample charts with examples of various levels of bird damage. ${ }^{19,20}$

By using the arithmetic means, central tendency and accuracy of the damage estimates were determined. Statistical differences in damage between confectionery and oilseed hybrids and among study years were determined using analysis of variance. Yield was estimated using the system described by The Sunflower article "How to Estimate Yield ${ }^{19 "}$ and Kandel, ${ }^{20}$ which accounts for five elements affecting yield: (1) plant population, (2) head diameter, (3) seed size, (4) percentage of seedset with no bird damage, and (5) center seedset. Each of the first three elements will have a corresponding multiplier $\left(\mathrm{M}_{i=1, \ldots, 3}\right)$ (Table 2). Equation ( 1$)$ is used to estimate overall yield:

Yield $(\mathrm{lbs} / \mathrm{ac})=2450 \times($ plant population $) \times\left(\mathrm{M}_{1}\right) \times($ head size $)$ $\times\left(M_{2}\right) \times($ seed size $) \times\left(M_{3}\right) \times(\%$ seedset without bird damage $)$

$\times($ center seed set)

We multiplied the result by 1.12085 to convert to $\mathrm{kg} \mathrm{ha}^{-1}$. Further details on how fields were examined and what the losses entail are included in Kandel and Linz ${ }^{18}$. Not all states had damages large enough to register a measurable regional economic impact 


\begin{tabular}{|lccccc|}
\hline \multicolumn{4}{|l|}{ Table 1. Average annual sampled sunflower damage and yield in eight states from the field study, 2009-2013 } \\
$\begin{array}{l}\text { Combined study } \\
\text { region }\end{array}$ & $\begin{array}{c}\text { Mean fields } \\
\text { sampled }(N)\end{array}$ & $\begin{array}{c}\text { Mean } \\
\text { harvested acres }\end{array}$ & $\begin{array}{c}\text { Mean yield } \\
\left(\mathrm{kg} \mathrm{ha}^{-1}\right)\end{array}$ & $\begin{array}{c}\text { Mean bird } \\
\text { damage (\%) }\end{array}$ & $\begin{array}{c}\text { Mean value (US\$) } \\
\text { of damage per ha }\end{array}$ \\
\hline Oilseed & 89 & 69851 & 1458 & $2.59 \%$ & 18.65 \\
Confectionary & 23 & 15120 & 1422 & $1.66 \%$ & 18.25 \\
\hline
\end{tabular}

\begin{tabular}{|c|c|c|c|c|c|}
\hline \multicolumn{2}{|c|}{ Plant population } & \multicolumn{2}{|c|}{ Seed size } & \multicolumn{2}{|c|}{ Head size } \\
\hline plants/acre & M1 & Size & M2 & Diameter (inches) & M3 \\
\hline 14000 & 0.70 & Light & 0.8 & 4.5 & 0.37 \\
\hline 15000 & 0.75 & Medium light & 0.9 & 5.0 & 0.46 \\
\hline 16000 & 0.80 & Medium & 1.0 & 5.5 & 0.55 \\
\hline 17000 & 0.85 & Medium heavy & 1.1 & 6.0 & 0.64 \\
\hline 18000 & 0.90 & Heavy & 1.2 & 6.5 & 0.73 \\
\hline 19000 & 0.95 & & & 7.0 & 0.82 \\
\hline 20000 & 1.00 & & & 7.5 & 0.91 \\
\hline 21000 & 1.05 & & & 8.0 & 1.00 \\
\hline 22000 & 1.10 & & & 8.5 & 1.09 \\
\hline 23000 & 1.15 & & & 9.0 & 1.18 \\
\hline 24000 & 1.20 & & & 9.5 & 1.27 \\
\hline 25000 & 1.25 & & & 10.0 & 1.36 \\
\hline 26000 & 1.30 & & & & \\
\hline
\end{tabular}

and therefore only three states, North Dakota, South Dakota, and Nebraska, were included in the regional economic analysis.

Further descriptive statistics for damage were calculated, including percent of head damaged, yield before damage, crop lost due to bird damage, dollars lost for oilseed and confectionery hybrids, and estimated total crop value lost per state, all averaged over the study years (Table 3 ). The mean level of damage was used to calculate the direct impact of blackbird depredation and was input into the REMI (Regional Economic Models, Inc.) model. The REMI model produced information regarding the regional economic impacts and reduction in employment resulting from blackbird crop depredation. All damage values are relative to the control scenario of no damage.

Potential yield $\left(\mathrm{kg} \mathrm{ha}^{-1}\right)$ for each state was calculated to reflect what would have been produced in the absence of bird damage. This was calculated by summing the average bird damage $\left(\mathrm{kg} \mathrm{ha}^{-1}\right)$ and the average annual production $\left(\mathrm{kg} \mathrm{ha}^{-1}\right)$ in each state for the 5 -year study period. ${ }^{21}$ These estimates were then used to provide direct inputs into a regional economic analysis.

\subsection{Regional economic analysis}

Regional economic analysis (REA) determines an estimation of secondary impacts associated with wildlife damage to macroeconomic indicators such as revenue, income, and jobs. Blackbird depredation of sunflower crops (the direct effect) generates measurable secondary impacts such as decreased sunflower oil production (indirect effect). Decreases in sunflower oil production impact the regional economy and can be measured using regional economic models. We constructed separate state level regional economic models of North Dakota, South Dakota, and Nebraska for this analysis based on national, state, and county level data from the Bureau of Economic Analysis, Bureau of Labor Statistics, and the Bureau of the Census, as well as forecasts from the Research Seminar in Quantitative Economics at Michigan State University. All results were calculated at the state level and then combined with the other states to represent the region.

Macroeconomic changes that arise from decreased sunflower production due to bird damage were analyzed using REMI PI+ software. REMI is a computer-based simulation model of the US economy that allows modeling at both the national and sub-national scales. This structural economic forecasting model uses a non-survey based input-output (I-O) table, which models the linkages among industries and households of a regional economy. ${ }^{12}$ Using the REMI model, we can generate forecasts that detail behavioral responses to changes in price, production, and other economic factors. ${ }^{22}$ In other words, REMI can model the impact that changes in the agricultural sector might have on other sectors of the economy and predict changes in employment and income in those sectors. For example, a decrease in sunflower production may result in decreased spending at local restaurants and retail shops, which in turn generates job loss at those businesses. This decreased income among workers then translates into a further decrease in spending. Capturing these ripple effects, or multiplier effects, is vital to understanding the total impact a change in one sector has on the entire regional economy. ${ }^{23}$ Modeling impacts in this way can translate blackbird damage to sunflower crops into regional (e.g. local, state, province) impacts on revenue and jobs, expanding the general public's perception of blackbird impacts.

\section{RESULTS}

Field results found that $15 \%$ of the surveyed fields had $>5 \%$ bird damage. ${ }^{18}$ In North Dakota, annual blackbird damage was found to be $8.7 \%$, valued at \$US10.7 million for both oilseed and confectionery type. Additionally, the average annual total 
Table 3. Average sunflower damage and value lost due to bird depredation in each of the eight states in the study region from 2009 to 2013

\begin{tabular}{|c|c|c|c|c|c|c|}
\hline Hybrid & State & $\begin{array}{l}\text { Percent head } \\
\text { damaged }\end{array}$ & $\begin{array}{c}\text { Average yield before } \\
\text { damage }\left(\mathrm{kg} \mathrm{ha}^{-1}\right)\end{array}$ & $\begin{array}{l}\text { Average crop } \\
\text { lost }\left(\mathrm{kg} \mathrm{ha}^{-1}\right)\end{array}$ & $\begin{array}{l}\text { Average US\$ } \\
\text { lost per ha }\end{array}$ & $\begin{array}{l}\text { Total value of } \\
\text { crop lost (US\$) }\end{array}$ \\
\hline \multirow[t]{8}{*}{ Oilseed } & $\mathrm{CO}$ & $0.34 \%$ & 1156.24 & 5.17 & 2.53 & 69710 \\
\hline & KS & $1.05 \%$ & 1513.59 & 20.11 & 9.86 & 558581 \\
\hline & MN & $0.84 \%$ & 1743.60 & 15.19 & 7.45 & 133730 \\
\hline & $\mathrm{NE}$ & $5.24 \%$ & 1341.95 & 73.81 & 36.17 & 359661 \\
\hline & ND & $4.20 \%$ & 1773.91 & 74.36 & 36.43 & 8708114 \\
\hline & SD & $1.74 \%$ & 1819.67 & 34.81 & 17.05 & 3394771 \\
\hline & TX & $0.26 \%$ & 1241.06 & 3.04 & 1.49 & 25648 \\
\hline & VT & $7.23 \%$ & 1694.37 & 120.23 & 58.91 & 11210 \\
\hline \multirow[t]{7}{*}{ Confectionary } & $\mathrm{CO}$ & $0.54 \%$ & 1584.72 & 8.07 & 5.33 & 72268 \\
\hline & KS & $0.00 \%$ & 1716.16 & 0.00 & - & - \\
\hline & MN & $0.84 \%$ & 1761.89 & 13.27 & 8.76 & 70980 \\
\hline & $\mathrm{NE}$ & $5.80 \%$ & 1733.55 & 142.20 & 93.85 & 1234037 \\
\hline & ND & $4.48 \%$ & 1764.37 & 81.23 & 53.61 & 2019408 \\
\hline & SD & $1.73 \%$ & 1905.14 & 35.74 & 23.59 & 905127 \\
\hline & TX & $0.00 \%$ & 1390.74 & 0.00 & - & - \\
\hline
\end{tabular}

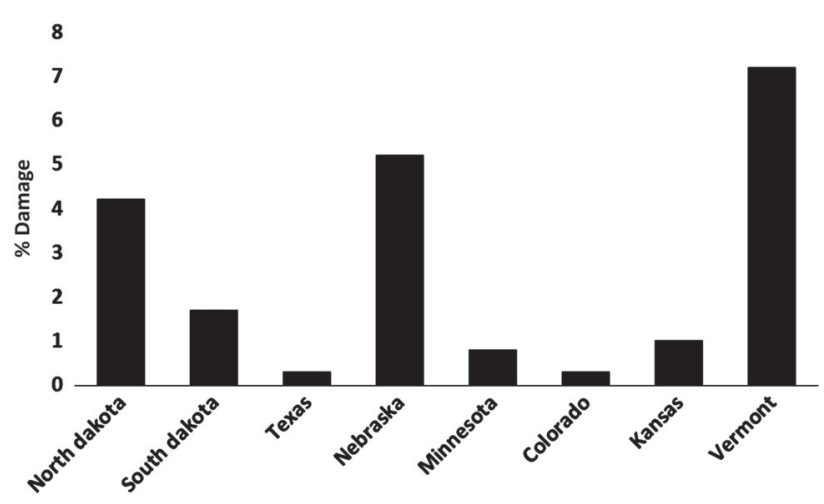

Figure 1. Field study average percentage of blackbird damage per hectare, per year to oilseed sunflower from 2009-2013.

(direct plus indirect) economic impact of bird damage to sunflower production in North Dakota was \$US18.7 million, which resulted in a reduction of an equivalent of seven jobs annually. Annually, blackbirds reduced sunflower yields by an average $4.2 \%$ (Fig. 1) and $4.5 \%$ (Fig. 2) and had direct statewide damages valued at \$US8.7 million and \$US2 million for oilseed and confectionery hybrids, respectively. Of the eight surveyed states, North Dakota ranked first in total bird damage for both confectionery and oilseed hybrids.

South Dakota reported an average annual total economic impact of bird damage to sunflower production of \$US7.3 million and reduced employment by two jobs. Annually, blackbirds reduced sunflower yields by $1.7 \%$ (Figs 1 and 2) in both oilseed and confectionery hybrids. Statewide direct damage was valued at \$US0.9 million and \$US3.4 million for confectionery and oilseed hybrids, respectively. Of the eight surveyed states, South Dakota ranked third in total bird damage to confectionery and second in total bird damage to oilseed hybrids.

Average annual total economic impact to Nebraska from bird damage to sunflower production was estimated at \$US2.6 million. Annually, blackbirds reduced sunflower yields by $5.24 \%$ (Fig. 1) and $5.8 \%$ (Fig. 2) and had direct statewide damage valued at \$US359 661 and \$US1.2 million for oilseed and confectionery hybrids,

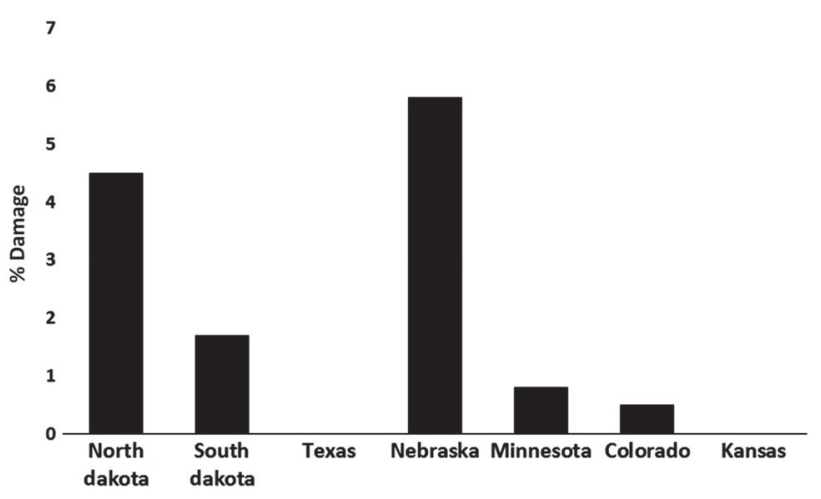

Figure 2. Field study average percentage of blackbird damage per hectare, per year to confectionery sunflower from 2009-2013.

respectively. Of the eight surveyed states, Nebraska ranked second in total bird damage to confectionery and fourth in total bird damage to oilseed hybrids.

Overall in the eight states sampled, the average annual total economic impact for bird damage to sunflower production was \$US29.5 million and reduced employment by 14 jobs. Reducing sunflower yields by averages of $2.59 \%$ and $1.66 \%$, blackbirds also caused direct damage valued at \$US13.26 million and \$US4.3 million within the eight states sampled per year for oilseed and confectionery hybrids, respectively (Figs 3 and 4). Average damage per hectare for oilseed was \$US18.65 and for confectionery was \$US18.25.

\section{DISCUSSION}

Our analysis estimates not only the direct impact of reduced sunflower yield but also provides an estimate of the regional economic impact of these losses to the broader economy. This is an important contribution to existing literature on bird damage that provides a more comprehensive understanding of the impact of bird depredation to sunflower crops. Results indicate that blackbird damage to sunflower is substantial and damages were most significant in North Dakota, South Dakota, and Nebraska, with each 


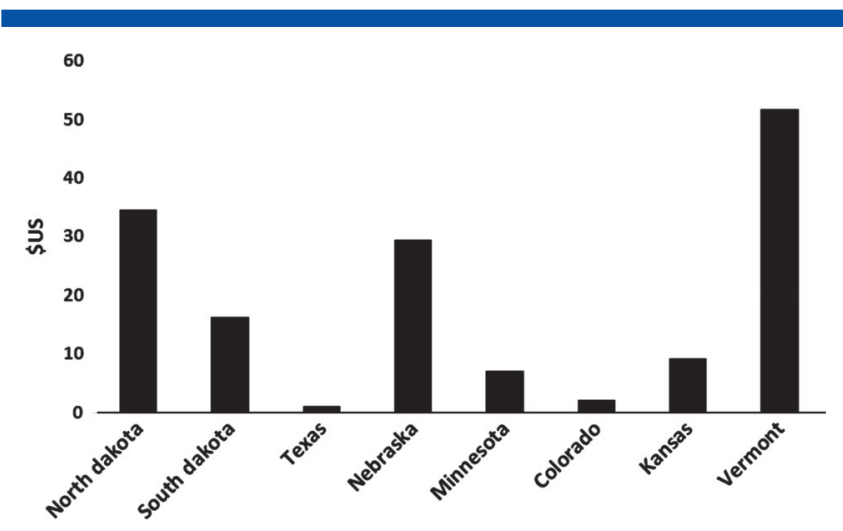

Figure 3. Field study average value of blackbird damage per hectare, per year $\left(\$ \mathrm{US} \mathrm{ha}^{-1}\right)$ to oilseed sunflower from 2009-2013.

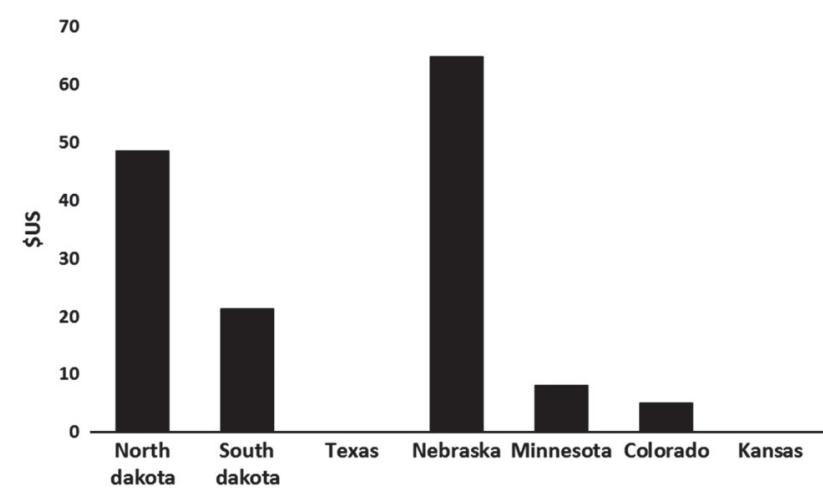

Figure 4. Field study average value of blackbird damage per hectare, per year $\left(\$ \mathrm{US} \mathrm{ha}^{-1}\right)$ to confectionery sunflower from 2009-2013.

resulting in averaged annual economic damages of \$US18.7 million, \$US7.3 million, and \$US2.6 million, respectively. Although the overall economic damage in North Dakota, South Dakota, and Nebraska was by far the largest, it is interesting to note that Vermont suffered the greatest per hectare damage to oilseed sunflower (Fig. 3). This may be due to the very small acreage available for birds to consume. On average, the total economic value lost to blackbird depredation in all eight studied states over the 5-year study period was over \$US87 million. By determining that North Dakota, South Dakota, and Nebraska are the states most significantly affected, we can focus on sunflower protection and blackbird mitigation programs more specifically in these states to deter future damages that may occur.

The results of this study serve two important functions. First, this study provides an idea of the broader economic implications of bird damage to sunflower by estimating the macroeconomic impacts of lost sunflower production in the region. Bird damage to sunflower or any crop is not simply a producer problem that only impacts producer profits. Removal or damage to sunflower by birds has downstream implications that ultimately can land on the consumer in the form of higher prices. By measuring some of the downstream impacts, this study illuminates how the region is impacted from this loss. While the producer does not necessarily realize all of the benefits associated with reduced bird depredation to crops, it is important that individuals not linked to production understand the benefits that sunflower production creates in the region in which they reside. In this way, the general public can be involved in meaningful discussion regarding the types of management methods used and the value of those management methods beyond the farm gate. This has the potential to greatly increase the acceptability of management methods and is crucial to the success of most management programs.

Second, the findings of this study may be used to inform decisions regarding bird management policy by providing policymakers with information to determine the downstream value of bird management and the possible benefits of improved methods that further mitigate losses. Increasingly, producers are turning to non-lethal management options as improved mitigation methods are developed. These non-lethal options include chemical repellants, frightening devices, habitat modification to attract predator birds, and, most recently, the use of unmanned aerial systems (UAS). ${ }^{24-27}$ Lethal options such as shooting, trapping, and pesticides seldom yield satisfactory results because of issues related to practicality, environmental safety, cost-effectiveness, and wildlife stewardship. ${ }^{28,29}$ Damage management methods have different levels of efficacy and associated costs. It may be the case that a more expensive method provides greater savings in terms of sunflower seeds produced and therefore has greater benefits for the macroeconomy. This information could also be used when estimating the rate of return of new research for bird management. Policymakers, producers, researchers, and the public can benefit from a broader understanding of the impacts of bird damage and the potential value of bird management.

\section{ACKNOWLEDGEMENTS}

We thank all the survey participants for their hard work and dedication. We also thank the National Sunflower Association, Mandan, and North Dakota State University for providing survey funds.

\section{REFERENCES}

1 Blackwell BF, Huszar E, Linz GM and Dolbeer RA, Lethal control of red-winged blackbirds to manage damage to sunflower: an economic evaluation. J Wildlife Manag 67:818-828 (2003).

2 Linz GM, Homan HJ, Werner SW, Hagy HM and Bleier WJ, Assessment of bird management strategies to protect sunflower. Bioscience 61:960-970 (2011).

3 US Department of Agriculture Economic Research Service. Soy beans \& oil crops, sunflower seed. (2016b). http://www.ers.usda.gov/topics/ crops/soybeans-oil-crops/sunflowerseed.aspx. [Accessed January 26, 2017].

4 US Department of Agriculture, January Crop Production Report: 2017. (2018). http://www.sunflowernsa.com/stats/usda-reports/JanuaryAnnual-Crop-Production/2017-January-Annual-Crop-Production/ [Accessed January 28, 2019].

5 Peer BD, Homan HJ, Linz GM and Bleier WJ, Impact of blackbird damage to sunflower: bioenergetic and economic models. Ecol Appl 13:248-256 (2003).

6 Cummings JL, Guarino JL and Knittle EC, Chronology of blackbird damage to sunflowers. Wild Soc Bull 17:50-52 (1989).

7 Hothem RL, DeHaven RW and Fairaizl SD, Bird damage to sunflower in North Dakota, South Dakota, and Minnesota, 1979-1981. US Fish Wild Serv Tech Rep 15:1-11 (1988).

8 Klosterman ME, Linz GM, Slowik AA and Homan JH, Comparisons between blackbird damage to corn and sunflower in North Dakota. Crop Prot 53:1 - 5 (2013).

9 Leitch JA, Linz GM and Baltezore JF, Economics of cattail (Typha spp.) control to reduce blackbird damage to sunflower. Agric Ecosyst Environ 65:141-149 (1997).

10 Linz GM and Homan HJ, Use of glyphosate for managing invasive cattail (Typha spp.) to protect crops near blackbird (Icteridae) roosts. Crop Prot 30:98-104 (2011).

11 Hirsch SA and Leitch JA, The impact of knapweed on Montana's economy. Ag Econ Rep No 355:5-43 (1996).

12 Shwiff SA, Kirkpatrick KN, DeVault TL and Shwiff SS, Bioeconomic modeling of double crested cormorant impacts to a recreational fishery. Human-wildlife Interactions 9:36-47 (2015). 
13 Berglund DR, National Sunflower Association Survey: Yield, Cultural Practices and Yield Limiting Factors. North Dakota State University, ND. (2009) http://www.sunflowernsa.com/uploads/research/ 376/Berglund NSASurvey 10.pdf [Accessed January 26, 2017].

14 Kandel H, 2010. National Sunflower Association Survey: Yield cultural practices and yield limiting factors. (2010) http://www.sunflowernsa .com/uploads/research/561/kandel_nsasurvey_11b.pdf [Accessed January 26, 2017].

15 Kandel H, 2011. National Sunflower Association Survey: Yield cultural practices and yield limiting factors. (2011) http://www.sunflowernsa .com/uploads/research/1140/2011.sunflower.survey.updated_ kandel_12.pdf [Accessed January 26, 2017].

16 Kandel H, National Sunflower Association Survey: Yield Cultural Practices and Yield Limiting Factors. (2012a) http://www.sunflowernsa.com/ uploads/research/1201/kandel_2012.nsa.survey_13.pdf [Accessed January 26, 2017].

17 Kandel H, National Sunflower Crop Survey (2013). http://www .sunflowernsa.com/uploads/research/1227/kandel_2013.crop .survey_paper_2014.pdf [Accessed 26 January 2017].

18 Kandel $\mathrm{H}$ and Linz GM, Blackbird damage is an important agronomic factor influencing sunflower production. Wildlife Damage Management Conference 16:75-82 (2016).

19 How to estimate yield, The Sunflower (2008). http://www.sunflowernsa .com/uploads/40/How_to_Estimate_Yield_Sept08.pdf Accessed January 16, 2017.

20 Kandel H, Estimating Sunflower Yield. Crop and Pest Report. North Dakota State University, ND. (2012b) https://www.ag.ndsu.edu/cpr/ plant-science/estimating-sunflower-yield-8-16-12 [Accessed May $17,2017]$.

21 US Department of Agriculture, Quick Stats 2.0. US Department of Agriculture, National Agricultural Statistics Service, Washington,
DC. (2016a) https://quickstats.nass.usda.gov/ [accessed January 26, 2017].

22 Treyz Gl, Rickman DS and Shao G, The REMI economic-demographic forecasting and simulation model. International Regional Science Review 14:221-253 (1991).

23 Miller RE and Blair PD, Foundations of input-output analysis, in Input-Output Analysis: Foundations and Extensions. Cambridge University Press, Cambridge, England, pp. 10-68 (2009).

24 Avery ML, Werner SJ and Frightening Devices, Ecology and Management of Blackbirds (Icteridae) in North America. CRC Press, Boca Raton (2017).

25 Werner SJ and Avery ML, Chemical Repellents, in Ecology and Management of Blackbirds (Icteridae) in North America, ed. by Linz GM, Avery ML and Dolbeer RA. CRC Press, Boca Raton, pp. 135-158 (2017).

26 Shave ME, Shwiff SA, Elser JL and Lindell CA, Falcons using orchard nest boxes reduce fruit-eating bird abundances and provide economic benefits for a fruit-growing region. J Appl Ecol 55:2451-2460 (2018).

27 Bhusal S, Khanal K, Karkee M, Steensma KM and Taylor ME, Unmanned Aerial Systems (UAS) for Mitigating Bird Damage in Wine Grapes. Proceedings of the 14th International Conference on Precision Agriculture Montreal. Quebec, Canada (2018).

28 Linz GM, Bucher EH, Canavelli SB, Rodriguez E and Avery ML, Limitations of population suppression for protecting crops from bird depredation: a review. Crop Prot 76:46-52 (2015).

29 Dolbeer RA, Dynamics and management of blackbird populations, in Ecology and Management of Blackbirds (Icteridae) in North America, ed. by Linz GM, Avery ML and Dolbeer RA. CRC Press, Boca Raton, pp. 119-134 (2017). 